Latham, M. J., Sharpe, M. E. \& Sutton, J. D. (197 I). F. appl. Bact. 34, 425.

Lindsay, D. B. (1970). In Physiology of Digestion and Metabolism in the Ruminant p. 438 [A. T. Phillipson, editor]. Newcastle upon Tyne: Oriel Press.

McAllan, A B. \& Smith, R. H. (1972), Proc. Nutr. Soc. 29A.

Nicholson, J. W. G. \& Sutton, J. D. (1969). Br. F. Nutr. 23, 585.

Ørskov, E. R., Fraser, C. \& Kay, R. N. B. (r969). Br. F. Nutr. 23, 217.

Satter, L. D. \& Wiltrout, D. W. (1970). Fedn Proc. Fedn Am. Socs exp. Biol. 29, 692.

Sutton, J. D. (1968). Br. \%. Nutr. 22, 689.

Sutton, J. D. (1969). Br. F. Nutr. 23, 567 .

Sutton, J. D. \& Johnson, V. W. (1969). F. agric. Sci., Camb. 73, 459.

Sutton, J. D., Smith, R. H. \& Corse, D. A. (1970). In EAAP 5 th Symposium on Energy Metabolism, p. 49 [A. Schürch and C. Wenk, editors]. Zurich: Juris Druck u. Verlag.

van't Klooster, A. T. \& Rogers, P. A. M. (1969). Meded. LandbHogesch., Wageningen 69-rx, 3.

Walker, D. I. \& Nader, C. J. (1970). Aust. F. agric. Res. 21, 747.

Weston, R. II. \& Hogan, J. P. (1968). Aust. F. agric. Res. 19, 963.

Whitelaw, F. G., Hyldgaard-Jensen, J., Reid, R. S. \& Kay, M. G. (r970). Br. Э. Nutr. $24,179$.

\title{
Intestinal absorption of carbohydrates in man
}

By H. B. McMichael, Department of Gastroenterology, Central Middlesex Hospital, Park Royal, London NWio

Carbohydrates provide about half the total calories in the diet of the average household in this country (Greaves \& Hollingsworth, I964). Typically, nearly twothirds of this ingested carbohydrate are derived from starch, about a quarter from sucrose and about a tenth from lactose. All this carbohydrate is hydrolysed to monosaccharides prior to absorption, producing approximately $250 \mathrm{~g}$ glucose, $40 \mathrm{~g}$ fructose and io $\mathrm{g}$ galactose.

\section{Rate-limiting factors in carbohydrate digestion and absorption}

Digestion and absorption take place in three phases: the intraluminal phase, the brush-border phase and the final absorption of the resultant monosaccharides.

\section{Intraluminal phase}

Starch hydrolysis by pancreatic $\alpha$-amylase ( $E C$ 3.2.I.I.) appears to be very efficient. Dahlquist \& Borgström (196r), using a post-liquid meal sampling technique at varying levels of the small intestine, found that each carbohydrate molecule consisted of, on average, less than three glucose units. Auricchio, Pietra \& Vegnente ( 1967 ) took samples from the distal duodenum in infants and young children after a test-meal containing amylopectin. Although the mean number of glucose units per molecule was $5^{-9}$ in infants up to 6 months old, the amylopectin contained over 5000 glucose units per molecule, so this represents very efficient hydrolysis even at this proximal point of the intestine.

There is, however, evidence to suggest that starch absorption continues even after surgical removal of the whole pancreas (Gaston, 1948). While salivary amylase and gastric acid hydrolysis may be of some importance, there is much amylase activity in the intestinal brush borders. 
Brush-border phase

Starch. Pancreatic $\alpha$-amylase can break starch into maltose ( $1: 4 \alpha$ glucose : glucose), maltotriose (three glucose units linked by $\alpha$ I:4 bonds), and the so-called $\alpha$-limit dextrins, which have a branch $\alpha \mathrm{I}: 6$ linkage.

We separated the disaccharidases by ion-exchange chromatography (McMichael $\&$ Dahlqvist, unpublished) and found that each of the maltases ( $\alpha$-glucosidase ( $E C$ 3.2.I.20)) was active on the malto-oligosaccharides, and on starch itself. Their mode of action is different from that of pancreatic amylase, in that they break off single glucose molecules from the end of a starch molecule. Similarly, the isomaltases ( $\alpha$-glucosidase ( $E C$ 3.2.I.20)) are able to hydrolyse large molecules with $\alpha \mathrm{I}: 6$ linkages (for example dextran).

The usual function of these brush-border enzymes is evidently to complete the hydrolysis of starch started by pancreatic $\alpha$-amylase. These enzymes have, however, much greater hydrolytic capacity in vivo than is required for this relatively simple task, and they can also hydrolyse whole starch molecules unaided by pancreatic $\alpha$-amylase. Ugolev ( 1965 ) found that the activity of pancreatic $\alpha$-amylase was potentiated by its adsorption on to the mucosa, and this he ascribed to an undefined property of the membrane. This potentiation can, however, be explained by the interaction at this site of the pancreatic and mucosal amylases with their different characteristics (McMichael \& Dahlquist, 1968).

Sucrose. Sucrose is hydrolysed by brush-border sucrase into glucose and fructose. The rate of absorption is identical, regardless of whether the sugar is presented to the mucosa as the disaccharide or the component monosaccharides (Gray \& Ingelfinger, I966).

Lactose (normal subjects). There is some disagreement as to whether lactose absorption is limited by lactose hydrolysis (Gray \& Santiago, r966; McMichael, Webb \& Dawson, 1967). The disagreement may arise as a result of the difference in definition of lactase ( $\beta$-galactosidase $(E C$ 3.2.x.23)) deficiency (see later). Our own results for the absorption of the disaccharides maltose, sucrose and lactose and the relevant mucosal disaccharidase activity are summarized in Fig. I.

In view of the multiplicity of enzymes with $\beta$-galactosidase (lactase) activity, only one of which has brush-border activity (Gray \& Santiago, r969), inclusion of lactase-deficient subjects would be illogical (McMichael et al. 1967) and, therefore, they have been omitted from the graph. There is clearly no correlation between the absorption and the in vitro disaccharidase activities. Although the mean absorption from lactose was slightly (but not significantly) lower than that from maltose, so was the absorption rate from the same relevant pair of monosaccharide components (Gray \& Santiago, I966).

Although total hydrolysis is less for lactose compared with maltose, we have already shown that disaccharidase activity is not the rate-limiting step for disaccharide absorption. Gray \& Ingelfinger (1966) showed that addition of galactose to a sucrose solution inhibited sucrose hydrolysis. This observation is compatible with the hypothesis that disaccharide hydrolysis is limited by product inhibition, and we have demonstrated inhibition of maltose hydrolysis by free glucose 


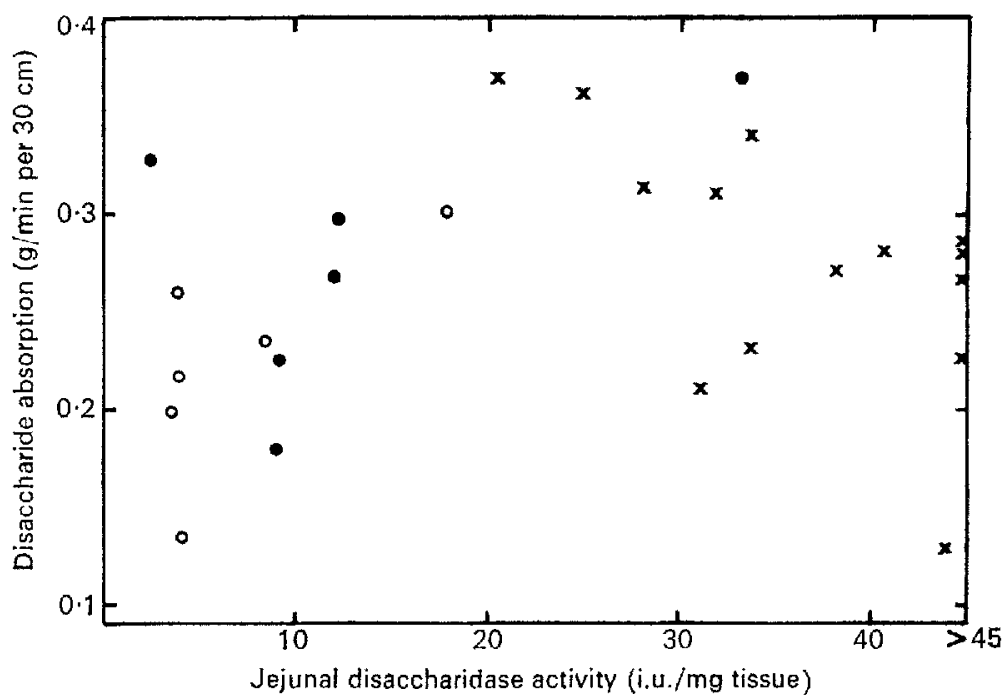

Fig. r. Absorption in man of three different disaccharides compared with the relevant jejunal mucosal disaccharidase activity (after McMichael et al. 1967). 0 , sucrose; $\times$, maltase; $O$, lactose (excluding lactase deficiency).

(McMichael and Dahlqvist, unpublished observations).

Conclusion. The evidence suggests that mucosal disaccharidase activity does not limit disaccharide absorption in the normal subject. The maltases are capable of hydrolysing starch with an efficiency which may well have some functional significance when pancreatic amylase is deficient. Isomaltase is essential for the hydrolysis of the $\alpha$-limit dextrins.

\section{Final membrane transport}

Glucose. This has been the subject of much work, especially in vitro (see review by Crane, I968) and has also been studied in living man (e.g. Holdsworth $\&$ Dawson, 1964). Glucose absorption behaves in accordance with ordinary enzyme kinetics (Fisher \& Parsons, I953).

Although $\mathrm{Na}^{+}$are necessary for in vitro transport of glucose, they do not appear to influence the rate of glucose absorption in vivo at the sugar concentrations present in the physiological state. Their absence may influence absorption when the intraluminal concentrations are very low (Olsen \& Ingelfinger, 1968).

Galactose. Although in vitro studies indicate that galactose shares the glucose carrier, it has not been found to inhibit glucose transport in vivo in man (Holdsworth \& Dawson, 1964), dogs (Annegers, I964) or rats (McMichael, unpublished observations). This unexpected finding raises the possibility that there may be two glucose pumps, one of which is not shared by galactose.

Fructose. Many experiments have shown that this does not share the glucose carrier but, in that it is absorbed faster than sorbose (Holdsworth \& Dawson, 
$1965 a)$, it must have some special carrier. Active transport of fructose has recently been demonstrated in vitro in the rat (Gracey, Burke \& Oshin, 1970).

Conclusion. Since the intraluminal and brush-border phases of hydrolysis do not limit absorption, evidently it is the final membrane transport of monosaccharides which is the rate-limiting step. The absorption is normally independent of intraluminal sodium concentration. There is a rare condition where the glucose-galactose carrier system is absent (Meeuwisse \& Melin, 1969).

\section{Rate-limiting factors in intestinal disease}

In the presence of mucosal damage, there is impairment of in vivo monosaccharide transport (Schedl \& Clifton, $196 \mathrm{I}$; Holdsworth \& Dawson, I965b) and of in vitro disaccharidase activity (Schmerling, Auricchio, Rubino, Hadorn \& Prader, 1964; McMichael, Webb \& Dawson, I966).

If it is correct that disaccharide hydrolysis is normally limited by accumulation of its reaction products, then the fact that disaccharide hydrolysis is reduced does not necessarily mean that the disaccharidases are rate-limiting. There is, however, evidence that lactase activity is particularly depressed in mucosal damage.

Perfusion studies by Gray \& Santiago (I966) show a greater degree of impairment of lactose hydrolysis and absorption than is accounted for by alteration in monosaccharide transport. While this suggests that lactase has become rate-limiting, these studies were performed in Puerto Ricans, who have a high incidence of primary lactase deficiency. The large standard errors support the idea that these subjects with tropical sprue may have had associated primary lactase deficiency. Reduction in absorption and hydrolysis of maltose and sucrose appears to be in proportion to impairment of monosaccharide transport.

In the presence of mucosal damage, therefore, it seems that depression of maltase and sucrase activity is of no functional importance. Depression of lactase activity may be of functional importance, although the evidence available in adults is open to some criticism.

\section{Ileal transport of carbohydrate}

It has been clearly shown that ileal transport of glucose is different from jejunal transport in vivo in dogs (Annegers, 1964), rats (Rider, Schedl, Nokes \& Shining, 1967; McMichael, unpublished observation) and probably in man (Schedl \& Clifton, 196r; Gray \& Ingelfinger, 1966). The differences are that the maximum absorption rates in the ileum are slower, which is hardly surprising teleologically but, also, that absorption is more efficient from lower concentrations, which would be of great advantage teleologically.

It is often claimed that, since carbohydrate absorption is so efficient from the upper intestine, none reaches the lower. Direct observations on this are few and conflicting (Borgström, Dahlqvist, Lundh \& Sjovall, I957; Dahlquist \& Borgström, I96I). Let us consider a grossly simplified, numerical example: suppose that, $50 \%$ sugar is absorbed in the upper quarter of the intestine (leaves $50 \%$ ), $50 \%$ sugar remaining is absorbed in the next quarter of the intestine (leaves $25 \%$ original), 
$50 \%$ sugar remaining is absorbed in the next quarter of the intestine (leaves $12.5 \%$ original), $50 \%$ sugar remaining is absorbed in the last quarter of the intestine (leaves $6.25 \%$ original). But $6.25 \%$ of the daily intake of $300 \mathrm{~g}$ carbohydrate is about I $8 \mathrm{~g}$ sugar. Expressed as isomolar monosaccharide solution, this would draw over $300 \mathrm{ml}$ water into the colon. If this was then metabolized by bacteria to $\mathrm{CO}_{2}$, the volume of gas produced would be $\mathrm{r} 31$. Of course, the point of enzyme kinetics is that relative efficiency increases at lower concentrations, but what I wish to emphasize here is that efficient absorption of ileal sugars may be of considerable importance when considering diarrhoea and flatulence.

\section{Mucosal disaccharidase deficiencies}

Maltases. All workers in this field are agreed that there are at least four separate maltases (Gray, 1970). Complete absence of maltase would imply simultaneous absence of multiple genes. This has never been described.

Sucrase. Only one group of workers claims more than one sucrase enzyme (Auricchio, Semenza \& Rubino, 1965), but this second sucrase may well have been an artefact (Dahlqvist \& Telenius, I 969 ). Sucrase deficiency is a well-recognized, though rare, congenital enzyme-defect (Burgess, Levin, Mahalanabis \& Tonge, 1964).

Isomaltase. It is usual to group together sucrase and isomaltase deficiencies. There is no question that the majority of isomaltase activity is inseparable (chromatographically) from sucrase activity. None the less, two features raise doubts on this simple interpretation. Firstly, in sucrase-deficient subjects, isomaltase activity is low but not absent (Anderson, Messer, Townley, Freeman \& Robinson, 1962). Secondly, these subjects are frequently not intolerant of starch (Burgess et al. 1964). Recent work (McMichael \& Dahlqvist, unpublished) indicates that three peaks of isomaltase activity may be separated, two of which have no sucrase activity. Although their activities are low compared with the main isomaltase, that does not necessarily mean that they limit hydrolysis rates.

Lactase. Auricchio, Rubino, Prader, Rey, Jos, Frezal \& Davidson (1965) first showed that only one of the two mucosal lactases was involved in primary lactase deficiency. This has most recently been confirmed by Gray, Santiago, Colver \& Genel (rg69), and the enzyme absent is that usually found in the brush borders of the mucosal cells.

Because of the wider specificity and $\mathrm{pH}$ optimum range of the intracellular lactase, it was not possible to measure the brush-border enzyme alone (this can now be done by using a specific inhibitor (Asp, Dahlqvist \& Koldovský, 1969)). For this reason there is much confusion about lactase deficiency throughout the literature. We studied the distribution of the disaccharidase activities and realized that they were distributed log-normally. Furthermore, there was no actual overlap between the normals and abnormals. As defined in this statistical way, there was excellent correlation with the results of lactose tolerance tests (McMichael et al. 1966) and, further, with perfusion studies of lactose absorption and hydrolysis (McMichael et al. 1967). Many of these lactase-deficient subjects did not have diarrhoea, even after taking lactose and certainly gave no history of milk intolerance. There would 
appear, however, to be good reason for classifying them as lactase-deficient. Many other authors (for example Newcomber \& McGill, 1966) have accepted lower levels of normality and specified that the patients must show lactose intolerance-at least after a lactose load.

The incidence of lactase deficiency varies greatly in different racial groups (Neale, r968). Indeed, it seems likely, since Chinese, most Africans and many Indians are affected, that on a world-scale it is the normal process for human adults to lose their brush-border lactase after weaning. In this respect about $94 \%$ of the British people are abnormal in retaining lactase activity into adulthood.

There are two possible explanations for this racial distribution. It may be genetically determined, or it may be due to dietary variation, lactase diminishing when milk is eliminated from the diet. Perhaps the best evidence in favour of a simple genetic aetiology is that of Cook \& Kajubi (x966) who found greatly differing incidence of lactase deficiency in different tribal groups of Uganda living under fairly similar dietary and other conditions.

That this is not the whole story is indicated by Bolin \& Davis (1970) who found that continued imbibing of milk by Chinese reduces the incidence of lactase deficiency among them. None the less, there is still a very high incidence of lactase deficiency even in these subjects.

Although maltase and sucrase activities are greatly influenced by diet, attempts to induce lactase by feeding lactose have produced equivocal results (Bolin, McKern \& Davis, 197I; Rosenweig, I97I). Furthermore, these studies have failed to separate the two mucosal lactases. Different principles are involved in increasing the activity of an enzyme already present and in inducing an enzyme which was lost as a result of genetic predetermination.

Congenital absence of sucrase activity is a clear-cut entity. It may not be associated with rate-limiting reduction in isomaltase activity. Primary lactase deficiency is genetically determined, occurs after weaning, and evidently cannot be reversed by feeding lactose to subjects already lactase-deficient.

\section{REFERENCES}

Anderson, C. M., Messer, M., Townley, R. R. W., Freeman, M. \& Robinson, M. J. (1962). Lancet ii, $55^{6}$.

Annegers, J. H. (г 964). Am. F. Physiol. 206, rog5.

Asp, N. G., Dahlquist, A. \& Koldovský, O. (1969). Biochem. F. rr4, 35 I.

Auricchio, S., Pietra, D. D. \& Vegnente, A. (I967). Pediatrics, Springfield 39, 853 .

Auricchio, S., Rubino, A., Prader, A., Rey, J., Jos, J., Frezal, S. \& Davidson, M. (1965). F. Pediat. 66, 555.

Auricchio, S., Semenza, G. \& Rubino, A. (1965). Biochim. biophys. Acta 96, 498.

Bolin, T. D. \& Davis, A. E. (1970). Australas, Ann. Med. x9, 40.

Bolin, T. D., McKern, A. \& Davis, A. E. (1971). Gastroenterology 6o, 432.

Borgström, B., Dahlqvist, A., Lundh, G. \& Sjovall, J. (1957). Ұ. clin. Invest. 36, 152 r.

Burgess, E. A., Levin, B., Mahalanabis, D. \& Tonge, R. E. (1964). Archs Dis. Childh. 39, 43 I.

Cook, G. C. \& Kajubi, S. K. (1966). Lancet i, 725 .

Crane, R. K. (1968). In Handbook of Physiology, Sect. 6, vol. 3, p. 1323 [C. F. Code, editor]. Washington D.C. : American Physiology Society.

Dahlqvist, A. \& Borgström, B. (196r). Biochem. \%. 81, 411.

Dahlqvist, A. \& Telenius, U. (1969). Biochem. F. Ir, 139.

Fisher, R. B. \& Parsons, D. S. (1953). F. Physiol., Lond. 119, 210. 
Gaston, E. A. (1948). New Engl. F. Med. 238, 345.

Gracey, M., Burke, V. \& Oshin, A. (1970). Lancet ii, 827 .

Gray, G. M. (1970). Gastroenterology 58, 96.

Gray, G. M. \& Ingelfinger, F. J. (1966). \%. clin. Invest. 45, 388 .

Gray, G. M. \& Santiago, N. A. (I966). Gastraenterology 5I, 489 .

Gray, G. M. \& Santiago, N. A. (Ig6g). \%. clin. Invest. 48, 7I6.

Gray, G. M., Santiago, N. A., Colver, E. H. \& Genel, M. (r 969$)$. F. clin. Invest. 48, 729.

Greaves, J. P. \& Hollingsworth, D. F. (1964). Proc. Nutr. Soc. 23, 136.

Holdsworth, C. D. \& Dawson, A. M. (I964). Clin. Sci. 27, 37 r.

Holdsworth, C. D. \& Dawson, A. M. (1965a). Proc. Soc. exp. Biol. Med. r18, 142.

Holdsworth, C. D. \& Dawson, A. M. $(1965 b)$. Gut 6, 387.

McMichael, H. B. \& Dahlqvist, A. (1968). Gut 9, 365 .

McMichael, H. B., Webb, J. \& Dawson, A. M. (1966). Br. med. F. ii, I037.

McMichael, H. B., Webb, J. \& Dawson, A. M. (r967). Clin. Sci. 33, г35.

Meeuwisse, G. \& Melin, K. (1969). Acta paediat., scand. suppl. 188, 3 .

Neale, G. (I 968 ). Hosp. Med. 2, 1372.

Newcomber, A. D. \& McGill, D. B. (r966). Gastroenterology 5r, $48 \mathrm{r}$.

Olsen, W. A. \& Ingelfinger, F. J. (1968). F. clin. Invest. 47, I 133 .

Rider, A. K., Schedl, H. P., Nokes, G. \& Shining, S. (1967). \%. gen. Physiol. 50, 1173.

Rosenweig, N. S. (I97I). Gastroenterology 60, 464 .

Schedl, H. P. \& Clifton, J. A. (1961). F. clin. Invest. 40, 1079.

Schmerling, D. H., Auricchio, S., Rubino, A., Hadorn, B. \& Prader, A. (1964). Helv. paediat. Acta I9, 507 .

Ugolev, A. M. (1965). Physiol. Rev. 45, 555.

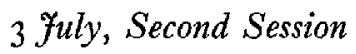

\section{Chairman : Professor A. T. Phillipson, MA, PhD, DVSc, MRCVS, School of Veterinary Medicine, University of Cambridge}

\section{Carbohydrate metabolism in the domestic fowl}

By J. Pearce, Department of Agricultural Chemistry, Queen's University of Belfast, Belfast BT, $6 B B$ and Ministry of Agriculture, Northern Ireland

In contrast to the situation in the mammal, particularly the rat for which there is a large volume of literature on carbohydrate metabolism, it is only in recent years that any concentrated effort has been made on this aspect of metabolism in the domestic fowl. This paper will review the present state of knowledge on intracellular carbohydrate metabolism during the development of the chicken and some interrelationships with lipid metabolism will also be discussed.

\section{Gluconeogenesis and glycogen metabolism in the embryonic and neonatal chick}

Glucose is necessary for the development of the chick embryo and since the hen's egg contains only traces of carbohydrate it is not unexpected that gluconeogenesis is active in the embryo (Kilsheimer, Weber \& Ashmore, I960; Ballard \& Oliver, I963). During incubation the gluconeogenic enzymes, pyruvate carboxylase (EC 6.4.r.r.), phosphopyruvate carboxylase ( $E C$ 4.I.I.32), hexosediphosphatase ( $E C$ 3.I.3.II) and glucose-6-phosphatase $(E C$ 3.x.3.9), increase in activity to maxima on the 